\title{
ANALISIS PENGARUH EQUITY TERHADAP NIAT UNTUK KELUAR ORGANISASI
}

\author{
Muhadi* \\ * Dosen STIKES Yayasan RS Dr.Soetomo Surabaya
}

\begin{abstract}
One form of side attitudes that threaten the existence of the organization is the intention to leave (the desire to get out) or thought to look for other employment alternatives. The general objective of this study was to analyze the influence of equity the intention to leave a permanent lecturer in STIKES Insan Unggul Surabaya. This type of research is an analytic study with a quantitative approach. Time approach used for this study is cross-sectional study design. This study was conducted in May 2013. The study sample as many as 34 respondents are tenured faculty in STIKES Insan Unggul Surabaya. Analyses were performed using ordinal regression and multinomial regression. The conclusion of this study is the ratio of the input (what was given such a commitment, workload, skill) bigger or higher than the output (what is obtained as development, compensation and satisfaction) of STIKES Insan Unggul Surabaya.
\end{abstract}

Keywords: Equity and Intention to leave.

Salah satu bentuk sikap yang mengancam keberadaan organisasi adalah niat untuk meninggalkan (keinginan untuk keluar) atau berpikir untuk mencari alternatif pekerjaan lain. Tujuan umum dari penelitian ini adalah untuk menganalisis pengaruh equity terhadap niat untuk keluar dosen tetap di STIKES Insan Unggul Surabaya. Jenis penelitian bersifat deskriptif dengan pendekatan kuantitatif. Pendekatan Waktu yang digunakan untuk penelitian ini adalah desain penelitian cross-sectional. Penelitian ini dilakukan pada bulan Mei 2013. Sampel penelitian sebanyak 34 responden dosen tetap di STIKES Insan Unggul Surabaya. Analisis dilakukan dengan menggunakan regresi ordinal dan regresi multinomial. Kesimpulan dari penelitian ini adalah rasio input (apa yang diberikan seperti komitmen, beban kerja, keterampilan) lebih besar atau lebih tinggi dari output (apa yang diperoleh pengembangan, kompensasi dan kepuasan) dari STIKES Insan Unggul Surabaya.

Kata kunci: Equity dan Niat untuk meninggalkan.

Sumber daya manusia dalam organisasi merupakan aspek terpenting menentukan keberhasilan organisasi. Untuk meMenghadapi persaingan pendidikan ilmu kesehatan, maka sekarang ini, Ssekolah Ttinggi Iilmu Kkesehatan (STIKES) harus mampu memiliki sumber daya manusia (SDM) yang berkualitas. Sumber daya manusia dalam organisasi merupakan aspek terpenting yang menentukan keberhasilan organisasi. Oleh karena itu organisasi senantiasa perlu melakukan perubahan dan pengembangan dengan melaksanakan fungsi manajemen sumber daya manusia secara optimal yang dimulai dari proses perekrutan, penempatan, standarisasi sampai menciptakan prestasi kerja, baik pada level personal dosen, program studi, level organisasi bahkan sampai dengan institusi lain.

Visi Sekolah Tinggi Ilmu Kesehatan (STIKES) Insan Unggul Surabaya untuk menjadi perguruan tinggi dibidang ilmu kesehatan yang terbaik di Jawa Timur pada 
tahun 2013 dan ditingkat nasional pada tahun 2018. Hal ini tentunya harus diimbangi dengan kekuatan dan kondisi sumber daya (resources) yang ada. Salah satu masukan dibutuhkan (input) organisasi yang sangat penting yaitu adalah sumber daya manusia (human resources) itu sendiri. Kualifikasi dan kualitas moral intelektual sumber daya manusia sangat menentukan kemajuan STIKES Insan Unggul.

Fenomena terhadap penurunan kinerja organisasi menurun tentunya dikembalikan kepada sejauh mana sumber daya manusia mengelola organisasi. Pemicunya adalah ditentukan oleh sikap dan pengetahuan karyawan. Saat ini STIKES Insan Unggul Surabaya mengalami perkembangan yang cukup pesat dengan ditandai makin meningkat jumlah mahasiswa yang mendaftar.

Salah satu bentuk sikap dosen yang mengancam eksistensi organisasi adalah adanya intention to leave (keinginan untuk keluar) atau pikiran untuk mencari alternatif pekerjaan lain. Hal ini juga dapat memicu sikap para karyawan untuk mengambil tindakan yang berujung pada keputusan karyawan untuk bekerja di tempat lain.

Organisasi akan mengalami hambatan dikarenakan karyawan yang tidak mengerahkan seluruh kemampuan yang dimiliki untuk mencapai tujuan organisasi karena adanya keinginan untuk pindah atau keluar. Akhirnya karyawan dengan kondisi yang kurang mendukung memutuskan untuk mencari alternatif lain atau keluar (leave). Beberapa penelitian menunjukan diantara faktor yang mempengaruhi niat pindah karyawan Maka dijelaskan data masalah di STIKES Insan Unggul pada tabel berikut :

Tabel 1.1 Data Intention to Leave Dosen Tetap di STIKES Insan Unggul Surabaya Tahun 2011-2012.

\begin{tabular}{ccccccc}
\hline Tahun & Respon & \multicolumn{6}{c}{$\begin{array}{c}\text { Intention to leave Dosen } \\
\text { Tetap }\end{array}$} & Jumlah \\
\hline 2011 & 23 & Ya & $\%$ & Tidak & $\%$ & $100 \%$ \\
& & 11 & 47,8 & 12 & 52,2 & \\
2012 & 28 & 18 & 64,3 & 10 & 35,7 & $100 \%$ \\
\hline
\end{tabular}

Sumber : Survey bulan Desember 2012.

Berdasarkan penjelasan uraian tabel data tersebut maka yang menjadi konsentrasi masalah penelitian adalah terjadi peningkatan intention to leave (keinginan untuk keluar) dari $47,8 \%$ menjadi $64,3 \%$ tenaga dosen tetap di STIKES Insan Unggul Surabaya.

Sejauh ini belum ada penanganan yang serius dilakukan oleh pihak STIKES Insan Unggul untuk mengurangi atau menekan intention to leave dosen tetap. Selain itu juga belum ada penelitian terkait penyebab intention to leave dosen tetap di STIKES Insan Unggul Surabaya, maka dipandang perlu untuk dilakukan suatu penelitian guna mengetahui faktor penyebab dan analisis terhadap masalah.

Penelitian ini dibatasi dan difokuskan pada pengaruh equity terhadap intention to leave dosen tetap di STIKES Insan Unggul. Penelitian lain yang dilakukan oleh bahwa persepsi terhadap keadilan (equity) mempengaruhi keinginan berpindah (intention to leave) karyawan disuatu perusahaan (Taris, 2002). Tujuan umum penelitian ini adalah menganalisis pengaruh equity terhadap niat untuk keluar (intention to leave) dosen tetap di STIKES Insan Unggul Surabaya.

\section{METODE}

Jenis penelitian ini merupakan penelitian analitik dengan pendekatan kuantitatif. Pendekatan waktu yang digunakan untuk penelitian yaitu rancang bangun cross sectional study, karena dilakukan pada periode waktu bersamaan atau tertentu terhadap variabel yang diteliti.

Penelitian ini dilakukan di STIKES Insan Unggul Surabaya. Pengambilan data dilaksanakan selama 2 (dua) bulan, dimulai pada bulan April s/d Mei 2013. Unit analisis dalam penelitian ini adalah individu yaitu dosen tetap di STIKES Insan Unggul Surabaya.

Populasi adalah wilayah generalisasi yang terdiri dari objek atau subjek yang menjadi kuantitas dengan karakteristik tertentu yang ditetapkan oleh peneliti untuk 
dipelajari dan ditarik kesimpulan. Populasi pada penelitian ini adalah seluruh dosen tetap STIKES Insan Unggul tahun 2013 sebesar 35 orang.

Sampel merupakan sebagian dari jumlah dan karakteristik yang dimiliki oleh populasi (Yamin, 2009). Sampel penelitian ini sebanyak 34 orang dosen tetap, satu orang responden cuti melahirkan.

Penelitian ini menggunakan kuesioner sebagai instrumen untuk mengumpulkan data primer. Kuesioner yang digunakan untuk mengumpulkan data pada setiap variabel dibuat dengan model pertanyaan tertutup.

Untuk mengetahui ada atau tidak adanya pengaruh antara variabel bebas terhadap variabel terikat (equity) dengan skala data yang beragam pada varibael independen maka digunakan uji regresi ordinal. (Yamin, 2009). Uji regresi ordinal cocok digunakan pada skala data yang sama ordinalnya.

\section{HASIL DAN PEMBAHASAN}

Equity teori didasarkan pada motivasi seseorang berdasarkan pada suatu pertimbangan terhadap rasa adil jika dibandingkan dengan orang lain (Redmond, 2010). Sebagai catatan oleh Gogia (2010) menyatakan bahwa teori ini diaplikasikan pada tempat kerja terutama difokuskan pada masalah kompensasi karyawan atau yang berhubungan dengan sistem imbalan. Sebagai contoh seorang karyawan mempersepsikan ketidakwajaran terhadap apa yang diamati ketika dia harus bekerja selama 40 jam per minggu (input) dan menerima $\$ 500$ (output) dibandingkan dengan rekan kerja lain bekerja selama 30 jam perminggu (input) dan menerima pembayaran $\$ 650$ (output).

Teori tentang keadilan (equity) pertama kali dikemukakan oleh Zalesnik (1958) kemudian dikembangkan John Stacey Adams, seorang ahli psikologi perilaku dan tempat kerja, yang menerbitkan jurnal equity theory terkait motivasi kerja pada tahun 1963. Ada kemiripan dengan pengembangan dan interpretasi yang dilakukan oleh Charles Handy terhadap teori kebutuhan Maslow, Herzberg dan perintis psikologi tempat kerja lainnya, yang semuanya mengakui adanya faktor dan variabel yang mempengaruhi penilaian individu dan persepsi hubungan dengan atasan mereka.

Jhon Stacey Adams pada tahun 1965 menekankan lebih jauh tentang kesadaran dan tanggung jawab dari situasi yang lebih luas dan lebih kompenhensif dibandingkan teori equity dalam banyak model teori motivasi sebelumnya. Teori ini dibangun akan keyakinan seseorang akan rasa keadilan dan persaan tidak adil sehingga dapat mendampak pada motivasi, sikap dan perilaku karyawan.

Beberapa penelitian menjelaskan perihal tentang kritik terhadap equity teori yaitu seperti yang dijelaskan oleh Redmond (2009) bahwa terkadang penilaiaan seseorang tidak sesuai dengan fakta, melainkan hanya subjektifitas atau asumsi yang tidak didukung oleh data valid sehingga memungkinkan persepsi yang dibangun seseorang menjadi keliru. Pada hasil lain (Redmond, 2009) semisal ada pilihan orang maka pemilihan terhadap opsi yang dipilih menjadi rumit apalagi jika tidak ada kriteria yang sesuai.

Kedua, misalnya berbagai kejadian terhadap transaksi yang berada diluar administrasi, managemen atau organisasi ada kemudian menjadi penilaian akan tidak adil, atau kondisi yang mereka lihat di luar dari itu. Ketiga, penelitian tentang kompensasi yang memberikan sedikit nilai (image) keburukan bagi organisasi (Redmond, 2009). Efek dari ketimpangan atau ketidak adilan yang ditemukan atau dipersepsikan menjadi pertimbangan utama dalam setiap keputusan dan diskusi organisasi. Disisi lain teori ini sangat sesnsitif jika menunjukan pembayaran kurang (underpayment) dapat memberikan respon cepat kepada pihak organisasi untuk segera mencari solusi masalah.

Elemen teori equity bersandar pada empat asumsi yaitu :

1) Teori ini menganggap bahwa orang mengembangkan kepercayaan terhadap organisasi tentang apa yang menyebabkan hasil yang diperoleh sebanding atas kontribusi yang ia diberikan dalam pekerjaan 2) Jika terjadi ketidaksetaraan maka akan terjadi ketegangan dan tekanan yang 
dirasakan oleh seorang karyawan dari penilaian tersebut.

3) Teori ini beranggapan bahwa orang cenderung membandingkan apa yang dipersepsikan harus menjadi timbal balik kepada mereka baik dengan organisasi ataupun dengan atasan.

4) Teori ini juga beranggapan bahwa ketika orang percaya bahwa hal tersebut tidak sebanding, maka mereka termotivasi untuk melakukan sesuatu atau merasa ada yang kurang.

Komponen dari teori ini adalah input, output, ratio input dan output, comparison person. Input adalah semua nilai yang dilakukan oleh karyawan yang menunjang pelaksanaan kerja, misalnya komitmen, pengorbanan, pendidikan, pengalaman, keterampilan, usaha, peralatan pribadi, waktu, jam kerja dll. Output adalah semua nilai yang diperoleh dan dirasakan karyawan, misalnya upah, keuntungan tambahan, pengakuan, kepuasan (satisfaction), kesempatan untuk berprestasi atau mengekspresikan diri dll.

Comparison person adalah seorang karyawan membandingkan dalam organisasi yang sama atau seorang karyawan dalam organisasi yang berbeda atau dirinya sendiri dalam pekerjaan sebelumnya. Oleh keinginan untuk diperlakukan secara adil maka mereka menilai orang disekitar. Persepsi keadilan tersebut akan menjelaskan berbagai sikap dan perilaku kerja. Equity teori pada awalnya berbasis pada teori pertukaran sosial (social exchange). Setiap individu berupaya mengharapkan bahwa mereka akan mendapatkan pertukaran usaha (effort) dan imbalan (reward) terutama terkait gaji (salary) secara adil dari organisasi (Tyler, 1989).

Fontaine (2010) mengemukakan pada sisi pembayaran karyawan terdapat 3 jenis penilaian equity; 1). Equity yaitu jika perbandingan faktor input dan output menjadi sama dengan rasio antara faktor input dan output yang seharusnya diperoleh oleh orang lain 2) Underpayment equity yaitu jika perbandingan faktor input dan output menjadi lebih kurang dari rasio antara faktor input dan output yang seharusnya diperoleh oleh orang lain 3) Overpayment equity yaitu jika jika perbandingan faktor input dan output menjadi lebih banyak dari rasio antara faktor input dan output yang seharusnya diperoleh oleh orang lain. Pada penelitian ini menggunakan hasil pengukuran sebagaimana yang diungkapkan oleh Gibson dkk (1997) tentang tiga jenis penilaian equity yaitu Adil, beruntung dan merasa kecewa.

Pinder (2008) mengemukakan beberapa contoh perbaikan tentang keadilan yang dilakukan individu atau karyawan :

1) Perubahan masukan (input) yaitu karyawan dapat menentukan bahwa ia akan mempergunakan lebih sedikit waktu atau banyak untuk bekerja.

2) Perubahan perolehan (output) yaitu karyawan dapat menetukan untuk memproduksi jenis usaha atau aktifitas lebih banyak karena pertimbangan imbalan.

3) Perubahan sikap dan cara padang (mindset) terhadap pekerjaan yaitu karyawan harus dapat bersikap kurang bersungguhsungguh terhadap pekerjaan.

4) Mengubah atau mengganti orang yang menjadi pembanding. Perubahan orang atau unit yang digunakan sebagai pembanding dalam upaya memulihkan keadilan.

5) Alternatif terakhir adalah mengubah situasi yaitu dengan memikirkan alternaitf lain (intention to leave) dan memustuskan untuk keluar adalah upaya untuk mengubah perasaan tidak adil yang dirasakan.

Kemudian beberapa penelitian terbaru menurut Redmond (2010) teori equity pada kondisi personal terjadi ketimpangan diri diakibatkan dari faktor yang membandingkan ratio input dan output yang diperoleh berbeda sehingga memunculkan ketidakadilan internal (internal inequity), kemudian mencoba untuk membandingkan dengan orang lain (comparison other) terkait kondisi personal yang dihadapi (eksternal equity).

Penilaian terhadap kondisi internal yang cukup objektif jika dilakukan sebagai suatu asessment karyawan sedangkan eksternal equity merupakan bahan pembanding bagi organisasi dalam menilai 
secara keseluruhan karyawan di tingkat bawah.

Adapun kata kunci dari equity theory menurut Redmond (2010) yaitu : a) Input : "Anything of value that a person to a job" b) Outcome : 'Benefits that a person is awarded from a job'c) Input/Outcome Ratio: "'The ratio of perceived of input compared to perceived of outcome'. d) omparison Other : "'Person or standard that an individual's input or outcome ratio is compared to', comparison other is not spesified by the theory,self reflection past experiences or an ideal (Redmond, 2010).

Faktor input pertama yaitu tentang komitmen adalah kemampuan untuk menyelaraskan prilaku pribadi dengan kebutuhan utama. Komitmen terhadap pekerjaan adalah kesetiaan, kepatuhan dan ketaatan serta dedikasi untuk mencurahkan segala pikiran dan kemauan pada bidang pekerjaan yang menjadi tanggung jawab. Menurut Meyer dan Allen (1994) komitmen juga berarti penerimaan yang kuat oleh individu terhadap tujuan dan nilai organisasi dan memiliki hasrat kuat untuk bertahan.

Menurut Luthans (1992), menyatakan bahwa komitmen organisasi merupakan: 1) Keinginan yang kuat untuk menjadi anggota dalam suatu kelompok. 2) Kemauan usaha yang tinggi untuk organisasi.3) Suatu keyakinan tertentu dan penerimaan terhadap nilai-nilai dan tujuan-tujuan organisasi. Komitmen keanggotaan secara umum dapat didefinisikan sebagai tingkat keterlibatan psikologis anggota pada organisasi tertentu. Keterlibatan psikologis ini akan tercermin pada tingkat aktivitas sesorang tersebut dalam suatu organisasi dan untuk kepentingan organisasi.

Jadi seseorang yang memiliki komitmen yang tinggi akan memiliki identifikasi terhadap organisasi, terlibat sungguhsungguh dalam kepegawaian dan ada loyalitas serta afektif positif terhadap organisasi, selain itu tingkah laku berusaha ke arah tujuan organisasi dan keinginan untuk tetap bergabung dengan organisasi dalam jangka waktu lama.
Faktor input kedua yaitu beban kerja merupakan beban aktivitas fisik, mental, sosial yang diterima oleh seseorang yang harus diselesaikan dalam waktu tertentu, sesuai dengan kemampuan fisik, maupun keterbatasan pekerja yang menerima beban tersebut.

Beban kerja adalah sejumlah kegiatan yang harus diselesaikan oleh seseorang ataupun sekelompok orang, selama periode waktu tertentu dalam keadaan

normal. Semua pekerjaan harus selalu diusahakan dengan sikap kerja yang ergonomis. Beban kerja dapat dibedakan atas beban kerja berlebih dan beban kerja sedikit atau kurang.

Di sisi lain beban kerja ditentukan oleh dua hal utama, yaitu kapasitas dan waktu. Kapasitas kerja merupakan berat ringannya beban kerja yang dapat diterima oleh tenaga kerja, dan dapat digunakan untuk menentukan berapa lama seseorang tenaga kerja dapat melakukan aktivitas sesuai dengan kemampuannya.

Semakin berat beban kerja, akan semakin pendek waktu kerja seseorang untuk bekerja tanpa kelelahan dan gangguan fisiologis yang berarti atau sebaliknya. Waktu kerja adalah penggunaan tenaga dan penggunaan organ tubuh secara terorganisasi dalam waktu tertentu.

Menurut UU No 13 Tahun 2003 pasal 77 ayat 1 , setiap pengusaha wajib melaksanakan ketentuan waktu kerja meliputi, 7 jam dalam sehari dan 40 jam seminggu untuk 6 hari kerja, atau 8 jam sehari dan 40 jam seminggu untuk 5 hari kerja. Selanjutnya pasal 79 ayat 1 , pengusaha wajib memberi waktu istirahat dan cuti kepada pekerja. Waktu istirahat dan cuti meliputi, istirahat antara jam kerja sekurangkurangnya setengah jam, setelah bekerja selama 4 (empat) jam terus menerus dan waktu istirahat tersebut tidak termasuk jam kerja, istirahat mingguan 1 (satu) hari untuk 6 (enam) hari kerja dalam seminggu, dan cuti tahunan sekurang-kurangnya 12 hari kerja, setelah pekerja yang bersangkutan bekerja selama 12 bulan secara terus menerus. 
Faktor input ketiga yaitu ketrampilan (skill) berarti kemampuan untuk mengoperasikan suatu pekerjaan secara mudah dan cermat yang membutuhkan kemampuan dasar (basic ability). Menurut Robbins (2006) pada dasarnya keterampilan dapat dikategorikan menjadi empat, yaitu:

1) Basic literacy skill yaitu keahlian dasar merupakan keahlian seseorang yang pasti dan wajib dimiliki oleh kebanyakan orang, seperti membaca, menulis

dan mendengar.

2) Technical skill yaitu keahlian teknik merupakan keahlian seseorang dalam pengembangan teknik yang dimiliki, seperti mengoperasikan komputer.

3) Interpersonal skill yaitu keahlian interpersonal merupakan kemampuan seseorang secara efektif untuk berinteraksi dengan orang lain maupun dengan rekan kerja, seperti pendengar yang baik, menyampaikan pendapat secara jelas dan bekerja dalam satu tim.

4) Problem solving yaitu menyelesaikan masalah adalah proses aktivitas untuk menajamkan logika, beragumentasi dan penyelesaian masalah serta kemampuan untuk mengetahui penyebab, mengembangkan alternatif dan menganalisa serta memilih penyelesaian yang baik.

Faktor Output pertama yaitu pengembangan dosen tetap yaitu mengembangkan pengetahuan, keterampilan dan kemampuan mereka melalui usaha yang diarahkan oleh diri mereka sendiri dan merespon lingkungan luar. Pengembangan diri merupakan bentuk perwujudan dari aktualisasi diri, yaitu proses untuk mewujudkan dirinya yang terbaik sejalan dengan potensi dan kemampuan yang dimilikinya. Setiap individu mempunyai kekuatan yang bersumber dari dirinya, namun banyak orang yang merasa tidak mempunyai kemampuan, merasa dirinya tidak berguna dan tidak mampu mencapai aktualisasi diri.

Para dosen harus mampu beradaptasi dengan perkembangan ilmu pengetahuan serta perubahan metode atau teknologi pendidikan yang berubah cepat, karena itu, dosen dituntut untuk terus meningkatkan kemampuan ilmiah dan kepribadiannya melalui berbagai upaya yang mungkin dilakukannya.

Faktor output kedua yaitu tentang kompensasi adalah pemberian balas jasa langsung dan tidak langsung, uang atau barang kepada karyawan sebagai imbalan jasa yang diberikan kepada organisasi. Prinsip kompensasi adalah adil dan layak. Adil diartikan sesuai dengan prestasi kerjanya, layak diartikan dapat memenuhi kebutuhan primernya serta berpedoman pada batas upah minimum pemerintah (Byars, 2003).

Salah satu cara manajemen untuk meningkatkan prestasi kerja, memotivasi dan meningkatkan kinerja para karyawan adalah melalui kompensasi. Menurut kompensasi adalah apa yang seorang pekerja terima sebagai balasan dari pekerjaan yang diberikannya. Menurut Luthans (1995) kompensasi mempunyai tiga komponen sebagai berikut : 1) Pembayaran uang secara langsung (direct financial payment) dalam bentuk gaji, dan intensif atau bonus. 2) Pembayaran tidak langsung (indirect payment) dalam bentuk tunjangan dan asuransi. 3) Ganjaran non finansial (non financial rewards) seperti jam kerja yang luwes dan kantor yang bergengsi.

Sistem pembayaran kompensasi yang umum diterapkan adalah 1) Sistem Waktu Sistem waktu, besarnya kompensasi (gaji, upah) ditetapkan berdasarkan standar waktu seperti jam, minggu, atau bulan. 2) Sistem Hasil (Output) sistem hasil, besarnya kompensasi/upah ditetapkan atas kesatuan unit yang dihasilkan pekerja, seperti per potong, meter, liter, dan kilogram. 3) Sistem borongan adalah suatu cara pengupahan yang penetapan besar jasa didasarkan atas volume pekerjaan dan lama mengerjakan.

Kepuasan kerja adalah sikap emosional yang menyenangkan dan mencintai pekerjaannya. Luthans (1995) menyatakan bahwa kepuasan kerja memiliki tiga dimensi, yaitu : (a) Kepuasan kerja adalah tanggapan emosional seseorang terhadap situasi kerja. Hal ini tidak dapat 
dilihat, tetapi hanya dapat diduga; (b) Kepuasan kerja sering ditentukan oleh sejauh mana hasil kerja memenuhi atau melebihi harapan seseorang.

Sebagai contoh, jika anggota organisasi merasa mereka bekerja lebih berat dari para anggota lainnya dalam suatu departemen, tetapi mereka merasa memperoleh penghargaan yang lebih sedikit daripada yang mereka harapkan, mereka mungkin akan bersikap negatif terhadap kerja, atasan dan rekan kerja mereka. Dilain pihak, jika mereka merasa diperlakukan dengan baik dan usaha yang telah mereka curahkan dihargai dengan adil, maka mereka akan bersikap positif terhadap kerja. Kepuasan kerja mencerminkan hubungan dengan berbagai sikap lain dari para individu.

Menurut Robbins (2006) kepuasan kerja sebagai suatu sikap umum seseorang individu terhadap pekerjaannya. Pekerjaan menuntut interaksi dengan rekan sekerja dan atasan, mengikuti aturan dan kebijakan organisasi, memenuhi standar kinerja, hidup pada kondisi kerja yang sering tidak ideal, dan hal serupa lainnya. Ini berarti penilaian seorang karyawan terhadap seberapa puas dan tidak puasnya dengan pekerjaannya.

Pengertian kepuasan kerja ini berkenaan dengan tingkah laku individu secara umum terhadap senang atau tidak senang terhadap pekerjaan. Seseorang yang memiliki kepuasan kerja yang tinggi maka seseorang memiliki tingkah laku yang positif terhadap pekerjaannya, sedangkan seseorang yang tidak puas akan memiliki tingkah laku yang negatif. Faktor yang mempengaruhi kepuasan kerja diantaranya adalah pekerjaan yang secara mental menantang, imbalan yang pantas, kondisi kerja, dan rekan kerja yang mendukung (Robbins, 2006).

Menurut model turnover intention (Mobley, 1986) ada lima kategori aspek pokok yang mendukung timbulnya turnover intention adalah :

\section{1) Pay (upah)}

Faktor terpenting dalam menentukan variasi antar industri dalam voluntary separation adalah tingkat upah yang relatif. Namun sejumlah hubungan antara tingkat upah menyebabkan pikiran untuk pindah ke perusahaan lain, oleh karena itu faktor upah merupakan pertimbangan utama.

\section{2) Integration}

Tingkat keikutsertaan atau keterlibatan karyawan dalam hubungan pokok dalam organisasi. Individu diangap memiliki peranan penting dalam proses roda organisasi. Hal ini dapat dilihat dari penting atau tidaknya keterlibatan atau partisipasi karyawan dalam berjalannya program perusahaan.

\section{3) Instrumental communication}

Instrumental communication berhubungan langsung dengan kinerja atau usaha karyawan. Mobley (1986) menemukan bahwa performance yang bagus sedikit yang menurunkan turnover intention.

\section{4) Formal communication}

Formal communication berkaitan dengan penyebaran informasi di antara anggota dari suatu sistem sosial organisasi. Mobley (1986) mengemukakan bahwa komunikasi formal organisasi merupakan faktor penentu turnover intention, yang dapat dilakukan dalam bentuk feedback terhadap tugas karyawan yang sering dan langsung, serta adanya saluran komunikasi formal yang terpercaya.

e) Centralization

Centralization merupakan tingkat dimana kekuasaan dipusatkan pada suatu sistem sosial. Price (1981) menyimpulkan bahwa pengalaman organisasi yang sangat terfokus pada pemimpin akan beresiko besar untuk terjadinya turnover intention. Hubungan ini didasarkan seperti faktor karyawan yang memiliki sedikit outonomy, tanggapan organisasi terhadap unit dan kebutuhan individu yang lambat, ataupun karyawan yang merasa bahwa karyawan tidak mempunyai kendali apapun didalam organisasi.

Berikut ini sejumlah hal yang telah dilakukan organisasi dalam memerangi masalah tingginya tingkat keluar masuknya karayawan menurut Price (1981) yaitu: a) Mengevaluasi kembali praktek perekrutan karyawan. Mungkin organisasi sedang mempekerjakan karyawan yang 
kualifikasinya terlalu tinggi dan tentu saja memiliki kemungkinan besar untuk merasa jemu atau tak puas b) Mempekerjakan kembali mantan karyawan. Ini bisa memberikan kesan kepada yang lain bahwa organisasi ini adalah sungguh tempat yang baik untuk bekerja jika sampai orang yang sudah keluar pun masuk kembali c) Mempertimbangkan pengembangan rencana pensiun atau pembagian keuntungan d) Meyakinkan diri bahwa organisasi telah membuat kesempatan bagi promosi adil dan dapat dimengerti dengan baik e) Membuka saluran komunikasi bagi manajemen. Ketika karyawan tak mengerti tujuan dari organisasi dan bagaimana hal itu akan mempengaruhi hidup mereka, rasa tak puas bisa berkembang f) Meningkatkan penggunaan insentif non finansial. Penghargaan terhadap prestasi kerja, tanggung jawab tambahan adalah beberapa cara untuk melakukan hak ini g) Melakukan interview untuk karyawan yang mau pindah kerja dan meninggalkan organisasi. h) Menanyakan kepada karyawan sekarang tentang apa yang mereka suka dan tidak suka dari hal yang dipraktekan di organisasi. Survei sikap merupakan cara baik untuk mendapatkan informasi. i) Melakukan penilaian secara teratur, para karyawan perlu tahu bagaimana kerja mereka.

Menurut Peraturan Pemerintah nomor 37 tahun 2009 tentang Dosen, dosen adalah pendidik profesional dan ilmuwan dengan tugas utama yaitu mentransformasikan, mengembangkan, dan menyebarluaskan ilmu pengetahuan, teknologi, dan seni melalui pendidikan, penelitian, dan pengabdian kepada masyarakat sedangkan dosen tetap adalah dosen yang bekerja penuh waktu yang berstatus sebagai tenaga pendidik tetap pada satuan pendidikan tinggi tertentu.

Kedudukan dosen sebagai tenaga profesional bertujuan untuk melaksanakan sistem pendidikan nasional dan mewujudkan tujuan pendidikan nasional yaitu berkembangnya potensi peserta didik agar menjadi manusia yang beriman dan bertaqwa kepada Tuhan Yang Maha Esa, berakhlak mulia, sehat, berilmu, cakap, kreatif, mandiri serta menjadi warga negara yang demokratis dan bertanggung jawab (UU no. 14 tahun 2005 tentang Guru dan Dosen).

Dosen tetap adalah tenaga pengajar yang menetap yang terikat kontrak dengan institusi yang bersangkutan dalam periode waktu tertentu. Kualifikasi akademi dosen diperoleh melalui pendidikan tinggi program pasca sarjana yang terakreditasi sesuai dengan bidang keahlian. Dosen memiliki kualifikasi akademi minimum lulusan program magister untuk program diploma atau program sarjana dan lulusan program doktor untuk program pascasarjana.

Beban kerja dosen mencakup kegiatan pokok yaitu merencanakan pembelajaran, melaksanakan proses pembelajaran, melaksanakan evaluasi pembelajaran, membimbing dan melatih, melakukan penelitian, melakukan tugas tambahan serta melakukan pengabdian pada masyarakat. Beban kerja sekurang-kurangnya sepadan dengan 12 (dua belas) satuan kredit semester (SKS) dan sebanyak banyaknya 16 (enam belas) satuan kredit semester (UU no.14 tahun 2005 tentang Guru dan Dosen).

Hasil penilitan ini menunjukan sebagian besar apa yang dikorbankan dan diberikan (input) oleh dosen tetap baik itu komitmen, beban kerja dan keterampilan lebih tinggi jika dibandingkan dengan apa yang dosen tetap peroleh berupa pengembangan, kompensasi, kepuasan.

Pimpinan harus mampu menumbuhkan komitmen dosen adalah dengan cara yaitu pertama, menumbuhkan sense of ownership adalah sangat penting terhadap STIKES Insan Unggul. Rasa memiliki merupakan prinsip dasar lahirnya komitmen. Kondisi ini akan tercapai bila manajemen melibatkan staff dosen dalam pengambilan keputusan karena sebagian besar dosen tetap tidak terlibat dalam pengambilan keputusan baik di tingkat institusi maupun program studi. Peneliti melihat manajemen memposisikan diri sebagai driver, sedangkan staff dosen lebih banyak disarankan hanya untuk bekerja.

Kecendrungan tidak demokratis dalam setiap keputusan dan tindakan. Aspek kedua adalah trust (kepercayaan) terhadap 
manajemen. Karyawan yang tidak punya kepercayaan kepada manajemen, kecil kemungkinan mereka mempunyai komitmen yang tinggi. Berbeda dengan jika ada kepercayaan, mereka tidak akan terpancing oleh setiap isu yang tidak benar di perusahaan, dan tidak mudah diprovokasi untuk melakukan mogok atau unjuk rasa.

Karyawan akan berusaha menunjukkan kemampuan terbaiknya dan merasa senang jika bisa memberikan yang terbaik kepada organisasi. Jika kondisi semacam ini bisa dicapai, maka tidak diperlukan pengawasan terus menerus terhadap kinerja karyawan bersangkutan.

Tabel 1.2 Internal Equity Berdasarkan Rasio Komitmen dan Pengembangan Dosen Tetap di STIKES Insan Unggul Surabaya Tahun 2013

\begin{tabular}{llrr}
\hline No & Kategori & Frekuensi & $\begin{array}{c}\text { Persentase } \\
(\%)\end{array}$ \\
\hline 1 & Beruntung & 8 & 23,5 \\
2 & Adil & 5 & 14,7 \\
3 & Kecewa & 21 & 61,8 \\
& Jumlah & 34 & 100 \\
\hline
\end{tabular}

Berdasarkan Tabel 1.2 diperoleh informasi bahwa rasio antara komitmen dan pengembangan sebagian besar berada pada kondisi kecewa. Hal ini menunjukan nilai komitmen (input) dosen tetap lebih tinggi jika dibandingkan dengan pengembangan (output) yang diperoleh. Sebagian kecil menunjukan kondisi yang beruntung yaitu komitmen lebih kecil dari pengembangan dosen.

Tabel 1.3 Internal Equity Berdasarkan Rasio Beban Kerja dan Kompensasi Dosen Tetap di STIKES Insan Unggul Surabaya Tahun 2013

\begin{tabular}{clrr}
\hline No & Kategori & Frekuensi & $\begin{array}{c}\text { Persentase } \\
(\%)\end{array}$ \\
\hline 1 & Beruntung & 11 & 32,4 \\
2 & Adil & 1 & 2,9 \\
3 & Kecewa & 22 & 64,7 \\
& Jumlah & 34 & 100 \\
\hline
\end{tabular}

Berdasarkan Tabel 1.3 diperoleh informasi bahwa sebagian besar rasio beban kerja dan kompensasi berada pada kondisi kecewa yaitu nilai beban kerja dosen tetap lebih tinggi jika dibandingkan kompensasi (direct payment) yang diperoleh. Aktifitas dan waktu digunakan dalam bekerja tergolong lebih tinggi, namun tidak sebanding dengan kompensasi (direct payment) yang diperoleh.

Tabel 1.4 Internal Equity Berdasarkan Rasio Keterampilan dan Kepuasan Dosen Tetap di STIKES Insan Unggul Surabaya Tahun 2013

\begin{tabular}{llrr}
\hline No & Kategori & Frekuensi & $\begin{array}{c}\text { Persentase } \\
(\%)\end{array}$ \\
\hline 1 & Beruntung & 17 & 50 \\
2 & Adil & 6 & 17,6 \\
3 & Kecewa & 11 & 32,4 \\
& Jumlah & 34 & 100 \\
\hline
\end{tabular}

Berdasarkan Tabel 1.4 diperoleh informasi bahwa sebagian besar rasio antara keterampilan dan kepuasan berada pada kondisi beruntung yaitu nilai keterampilan lebih rendah dari kepuasan yang diperoleh. Hal ini menunjukan kebanayakan dosen tetap merasakan kepuasan lebih tinggi jika dibandingkan dengan keterampilan (input) yang diberikan. Sebanyak 17,6\% dinilai adil atau sebanding dengan apa yang mereka terima. Faktor kepuasan di dominasi oleh sebagian besar dosen tetap di STIKES Insan Unggul.

Tabel 1.5 Equity Berdasarkan Perhitungan Internal Equity Dan Eksternal Equity Dosen Tetap di STIKES Insan Unggul Surabaya Tahun 2013

\begin{tabular}{|c|c|c|c|}
\hline No & Kategori & Frekuensi & $\begin{array}{c}\text { Persentase } \\
(\%)\end{array}$ \\
\hline 1 & Beruntung & 11 & 32,4 \\
\hline 2 & Adil & 1 & 2,9 \\
\hline 3 & Kecewa & 22 & 64,7 \\
\hline & Jumlah & 34 & 100 \\
\hline
\end{tabular}
informasi bahwa perhitungan antara internal equity dan eksternal equity dosen tetap berada pada kondisi kecewa. Hal ini menunjukan secara umum pada penelitian ini 
bahwa penilaian antara responden dan persepsi terhadap rekan kerja lain mengarahkan kepada kondisi apa yang diberikan atau dikorbankan (input).

Tabel 1.6 Kategori Penilaian Terhadap Intention to Leave Dosen Tetap di STIKES Insan Unggul Surabaya Tahun 2013

\begin{tabular}{llrr}
\hline No & Kategori & Frekuensi & $\begin{array}{c}\text { Presentase } \\
(\%)\end{array}$ \\
\hline 1 & Sangat & 2 & 5,9 \\
& Lemah & & \\
2 & Lemah & 14 & 41,2 \\
3 & Kuat & 13 & 38,2 \\
4 & Sangat Kuat & 5 & 14,7 \\
& Jumlah & 34 & 100 \\
\hline
\end{tabular}

Berdasarkan Tabel 1.6 diperoleh informasi bahwa sebagain besar dosen tetap tergolong dalam kondisi intention to leave yang kuat. Hal ini menunjukan sebagain besar dosen tetap meliki pikiran untuk keluar mencari alternatif lain yang lebih tepat dan sesuai dengan kondisi yang dialami. Intention to leave yang kuat mengarahkan pada kondisi organisasi yang kurang stabil.

Equity di dasarkan pada suatu keadaan yang membandingkan individu terhadap orang lain yang menuntut akan kesamaan atau keadilan, equity bukan didasarkan pada pertimbangan hubungan emosioanal semata. Ketiga, kemungkinan ada kekeliruan dalam proses penilaian dan pengolahan data baik pada saat penyusunan pertanyaan maupun penelitian. Keempat, ketika LMX tinggi atau baik, maka tidak ada perbedaan antara seseorang itu merasa adil maupun tidak adil terhadap apa yang dialami selam bekerja di STIKES Insan Unggul.

Hasil penelitian ini menunjukan bahwa apa yang mereka berikan (input) lebih besar dibandingkan dengan apa yang mereka peroleh (output). Komitmen dosen tetap tergolong lebih besar jika dibandingkan dengan kebutuhan akan pengembangan. Diantaranya kelompok pendidikan sarjana masih kurang memperoleh pengembangan dari STIKES.
Sebanyak $47,1 \%$ dosen tetap di STIKES Insan Unggul berpendidikan sarjana. Kelompok pendidikan sarjana membutuhkan tingkat pengembangan yang lebih dari pada kelompok magister, secara spesifik yang berkaitan dengan pelatihan dan pembelajaran menjadi dosen. Bagi dosen yang sudah S2 perlu diperkuat dengan keterampilan yang menunjang organisasi seperti SPMI, E-journal atau publikasi ilmiah yang mendukung kemampuan dosen.

Pihak Manajemen dipandang perlu untuk melihat kelompok yang masih sarjana guna menunjang standarisasi untuk menjadi tenaga dosen tetap di STIKES Insan Unggul Surabaya. Kualitas mengajar salah satunya ditentukan oleh jenjang pendidikan seorang pengajar, semakin tinggi jenjang pendidikan seseorang maka semakin memungkinkan untuk menghasilkan pengetahuan dan kapasitas mengajar yang baik (Fatmah, 2011). Secara umum seorang dosen harus memperoleh jenjang pendidikan magister untuk bisa menjadi dosen.

Sebagian besar dosen tetap berjenis kelamin perempuan sebanyak 85,3\%. Menurut Pinder (1981) bila mempelajari kepustakaan mengenai hubungan antara jenis kelamin dengan persepsi equity, maka tidak ditemukan pengaruh antara kedua variabel. Penelitian ini juga menjelaskan bahwa jenis kelamin tidak berpengaruh terhadap equity dosen tetap di STIKES Insan Unggul Surabaya. Tidak ada hubungan atau pengaruh terhadap persepsi dosen terhadap nilai equity.

Jenjang pendidikan dosen tetap sebanyak $47,1 \%$ orang adalah sarjana. Hal ini menunjukan dosen tetap masih banyak yang belum memenuhi kualifikasi sebagai dosen. Upaya dosen tetap untuk menempuh studi lanjut setidaknya mendapatkan respons dari pihak STIKES. Mekanisme bisa melalui institusi atau mengusulkan beasiswa ke pemerintah. Apabila dosen tersebut tidak memperoleh kesempatan menempuh pendidikan lanjut dari institusi, jika tidak mendapatkan pendanaan membiayai studi, maka mereka akan sulit kesulitan memenuhi kualifikasi dosen. 
Bukan tidak mungkin bila suatu saat dihadapkan pada persepsi seseorang terhadap ketidakadilan yang diterima akibat baik dari mekanisme maupun keterlambatan respon institusi. Pada penentuan seseorang yang disekolahkan, secara bertahap sudah dilaksanakan dengan mengirimkan para staff ke universitas yang dituju. Oleh karena itu organisasi perlu melakukan perencanaan untuk studi lanjut dari dosen tetap yang masih pada jenjang S1.

Upaya menenmpuh pendidikan lanjut dengan sistem ikatan dinas/kontrak dengan ketentuan ikatan masa kerja tertentu (Fatmah, 2011). Berdasarkan hasil diskusi dan wawancara dengan beberapa dosen sebagian besar dosen yang melanjutkan pendidikan telah mengikat kontrak dengan STIKES Insan Unggul Surabaya antara 4 s/d 8 tahun. Semakin tinggi tingkat pendidikan seseorang maka memungkinkan semakin besar output yang diperoleh.

Berdasarkan hasil penelitian ini sebanyak $73,5 \%$ status pernikahan dosen tetap sebagian besar sudah menikah. Menurut hasil uji statistik yaitu tidak ditemukan pengaruh antara dosen yang berstatus sudah atau belum menikah terhadap equity. Apabila pelamar yaitu calon dosen tetap yang berstatus belum menikah, sebaiknya lebih lanjut dipastikan bahwa calon dosen tersebut memiliki

Berdasarkan hasil penelitian ini bahwa faktor internal equity berpengaruh terhadap intention to leave dosen tetap di STIKES Insan Unggul. Internal equity penilaian terhadap personal dosen tetap terkait rasio input dan output yang diterima. Apa yang diberikan kepada pekerjaan, dengan artian seorang dosen tetap menyimpulkan tentang apa yang diterima. Lee (2000) menunjukan tingkat komitmen dan prestasi karyawan yang rendah berpengaruh pada tingginya intention to leave (Lee, 2000). Hasil penelitian Joo (2008) tentang hubungan antara komitmen tinggi dan turnover intention menunjukkan adanya hubungan yang positif. Sehingga hasil penelitian ini sesuai dengan hasil penelitian Lee (2000).
Pada aspek beban kerja, penelitian ini menunjukan sebagian besar dosen tetap di STIKES Insan Unggul selain menjadi dosen juga menjadi staff dalam organisasi. Hal ini setidaknya berpotensi kepada beban kerja dosen yang tinggi, disamping harus menjalani tugas utama sebagai dosen di sisi lain harus merangkap sebagai staff organisasi atau karyawan. Secara umum beban kerja dipengaruhi oleh berbagai faktor yang sangat kompleks, baik faktor external maupun internal.

Pengaruh faktor external adalah faktor yang mempengaruhi beban kerja yang berasal dari luar tubuh pekerja antara lain tugas yang dilakukan bersifat fisik seperti tempat kerja, sarana kerja dan sikap kerja. Depkes (2002), menyatakan bahwa pengelolaan tenaga kerja yang tidak direncanakan dengan baik dapat menyebabkan keluhan yang subyektif, beban kerja semakin berat, tidak efektif dan tidak efisien yang memungkinkan ketidakpuasan bekerja yang pada akhirnya mengakibatkan turunnya kinerja dan produktivitas serta mutu pelayanan yang merosot.

Penilaian terhadap training di STIKES Insan Unggul dari beberapa parameter sebagian besar dosen tetap tergolong kurang dalam memperoleh pelatihan eksternal dari STIKES misalnya pelathan e-jurnal, Aplikasi SPMI (Standar Penjaminan Mutu Internal). Beberapa dosen menyatakan pengembangan karyawan di STIKES Insan Unggul kurang proposional karena tidak memiliki mekanisme yang jelas dan tepat dalam memilih karyawan, lebih ditentukan oleh hubungan emosional antara leader dan member.

Komponen lain yang terpenting dari output adalah kompensasi. Berdasarkan hasil penelitian ini mayoritas dosen tetap menilai kurang dalam memperoleh kompensasi dan berpengaruh terhadap intention to leave. Hal ini sejalan dengan penelitian sebelumnya bahwa faktor gaji (underpayment) yang rendah mempengaruhi intention to leave sehingga menyebabkan karyawan keluar dari pekerjaan (Steers, 1981). 
Beberapa parameter pertanyaan terkait kompensasi yaitu sebagain besar menyatakan tidak setuju merasakan perubahan kenaikan yang baik. Parameter lain juga menunjukan STIKES belum menerapkan sistem gaji yang baik terhadap dosen tetap ataupun karyawan lainnya. Salah satu alasan kenapa dikatakan kurang dari beberapa responden menyatakan gaji (salary) yang diperoleh karena tidak sesuai dengan apa yang diusahakan (effort). Selain itu menyatakan juga tugas dan tanggung jawab bertambah tidak dibarengi dengan kenaikan gaji yang diperoleh oleh dosen tetap.

Aspek lain dari output juga adalah kepuasan kerja. Berdasarkan hasil penelitian diperoleh sebanyak $35,3 \%$ orang dosen menyatakan kurang puas. Menurut Fishbein (1975), hampir semua model intention to leave dikarenakan oleh tingkat kepuasan kerja dan komitmen organisasi yang rendah, yaitu: (1) kepuasan kerja adalah sikap yang paling berpengaruh terhadap intention to leave.

Hasil studi menunjukkan bahwa kepuasan kerja berkaitan erat dengan proses kognisi menarik diri (pre withdrawal cognition), intensi untuk pergi dan tindakan nyata berupa keputusan untuk keluar dari tempat kerja; (2) komitmen organisasi adalah faktor yang paling berpengaruh terhadap terjadinya intention to leave dibanding kepuasan kerja. Kepuasan kerja berpengaruh secara langsung terhadap keinginan berpindah karyawan.

Menurut penjelasan Fishbein (1975) dapat diambil kesimpulan bahwa setiap faktor yang dapat mempengaruhi kepuasan kerja harus diperhatikan oleh perusahaan. Karena dapat menyebabkan karyawan tidak puas dan meninggalkan pekerjaan serta mencari alternatif pekerjaan lain di luar organisasi. Adapun rasio input dan output dari penilaian terhadap responden yaitu dosen tetap di STIKES Insan Unggul sebagian besar dinilai apa yang diperoleh sama nilainya dengan apa yang diterima dari STIKES Insan Unggul.

Menurut

Robbins

(2006), ketidakpuasan karyawan terhadap gaji yang diterima akan menimbulkan dampak yaitu karyawan selalu mengeluh, membangkang, menghindari tanggung jawab pada pekerjaan sehingga bisa meninggalkan pekerjaan dengan sengaja, Sehingga pernyataan tersebut secara kondisi sama dengan di STIKES Insan Unggul. Secara umum berdasarkan hasil uji statistik bahwan equity berpengaruh terhadap intention to leave dosen tetap di STIKES Insan Unggul Surabaya.

\section{SIMPULAN}

Simpulan hasil penelitian yang diajukan dalam penelitian ini mengacu pada tujuan khusus penelitian dan pembahasan yang ada pada bab sebelum ini. Berdasarkan hasil tersebut maka dapat diperoleh kesimpulan sebagai berikut :

1. Rasio input (apa yang dosen tetap diberikan seperti komitmen, beban kerja, ketermapilan) lebih besar atau lebih tinggi jika dibandingkan dengan output (apa yang diperoleh seperti pengembangan, kompensasi dan kepuasan).

2. Sebagian besar dosen tetap memilki pikiran untuk keluar (intention to leave) jika dibandingkan dengan dosen tetap di STIKES Insan Unggul Surabaya yang memiliki pikiran untuk bertahan (intention to stay).

3. Equity yaitu faktor internal equity berpengaruh secara signifikan terhadap intention to leave dosen tetap di STIKES Insan Unggul Surabaya.

\section{SARAN}

Upaya yang dapat dilakukan oleh STIKES Insan Unggul Surabaya untuk memperbaiki persepsi dosen akan keadilan (fairness) di STIKES Insan Unggul Surabaya adalah dengan; untuk dapat menekan intention to leave dosen tetap maka beberapa hal yang perlu dilakukan oleh organisasi adalah dengan memperhatikan masalah kompensasi dan kualitas kepemimpinan 
(high leadership quality) yang berfungsi untuk menekan niat untuk keluar (intention to leave) dosen tetap di STIKES Insan Unggul Surabaya.

\section{DAFTAR PUSAKA}

Adams, J., 1963. Toward an understanding of inequity. Journal of Abnormal and Social Psychology, 67(5), pp. 422436.

Adams, J., 1965. Inequity in Social Exchange. Advances in Experimental Social Psychology, Volume II, pp. 267-299.

Al-Zawahreh, A \& Al-Madi., F, 2004. The Utility of Equity Theory in Enhancing Organizational Effectiveness. European Journal of Economics, Finance and Administrative Sciences, pp. 1-5.

Andini, 2006. Analisis Pengaruh Kepuasan Gaji, Kepuasan Kerja dan Komitmen Organisasi Terhadap Turnover Intention. Tesis, pp. 2729.

Azwar, S., 2005. Sikap Manusia Teori dan Pengukuran. Yokyakarta: Pustaka Pelajar.

Brown, B., 2003. Employee's Organizational Commitment and Their Perception of Supervisors Relations-Oriented and Task-Oriented Leadership Behaviors. Dissertation, pp. 178199.

Byars, L. L., 2003. Human Resources Management Tenth Editions. New York: Columbia Press.

Dansereau, F., Cashman, J., \& Graen, G. 1973. Instrumentaly theory and equity theory as complementary approaches in predicting the relationship of leadership and turnover among managers. Organizational Behavior \& Human Performance, 10, 184-200.

Fatmah, P., 2011. Pengaruh Kepuasan Kerja dan Komitmen Organisasi
Terhadap Turnover Intention. Tesis, pp. 27-39.

Fishbein, M \& Ajzen, 1975. Belief, Attitude, Intention, and Behavior: An Introduction to Theory and Reseach. Philippines: Addison Wesley Publishing Company.

Fitz-enz, J \& Davison, B, 2022. How to Measure Human Resources Management. 3th ed. United State of America: Mc Graw Hill.

Ganeshan, S \& Barton, A, 1996. The Impact of Staffing Policies on Retail Buyer Job Attitude and Behavior. Policies and Management, Volume 8, pp. 245-249.

Gibson, J.L., Ivancevich, J.M., \& Donnely, J.H, 1997. Organizational and Management. 4 ed. Jakarta: Erlangga.

Gogia, P. (2013, July 14). Equity theory of motivation. Retrieved from http://www.businessihub.com/equi ty-theory-of-motivation/.

Graen, G., \& Schiemann, W. 1978. LeaderMember agreement: A vertical dyad linkage approach. Journal of Apllied Psychology, 63, pp.206212.

Graen, G., \& Uhl Bien, M, 1995. Relationship based approach to leadership development of leader member exchange (LMX) theory of leadership over 25 years. Leadership Quaterly, Volume 6, pp. 219-247.

Griffin, M.A., Peterson, M.G \& West, M.A, 2001. Job Satisfaction Team Work :The Role of Supervisor Support. Journal of Organizational Behavior, Volume 22, pp. 537550.

Hackett, R.D., Bycio, P \& Hausdorf, P.A, 1994. Three Component Model of Organizational Commitment. Journal of Applied Phsychology, Volume 79, pp. 15-23.

Hassan, A \& Chandaran, S, 2005. Quality of Supervisor-Subordinate Relationship an Work Outcome; 
Organizational Justice As Mediator. Journal Economics and Management, Volume 1, pp. 346349.

Joo, B., 2008. The Antecendents and Consequence of Organizational Commitment : The Role of Organizational Learning Culture, Leader-Member Exchange Quality and Turnover Intention. Midwest Academy of Management, Volume II, pp. 220-223.

Lee, T.W., Ashford S.J \& Modway R.T, 1992. Commitment Propensity, Organizational Commitment and Voluntary Turnover: A Turnover Study of Organizational Entry Process. Journal of Management, Volume 18, pp. 15-32.

Luthans, F., 1995. Organizational Behaviour. 7 th ed. New Jersey: Prentice Hall Inc.

Miller, B., 2009. Confirmatory Factor Analysis of The Equity Preference Questionaire. Journal of Managerial Psychology, Volume 24, pp. 328-347.

Mobley, W., R. Griffith, H. Hand and B. Meglino. 1979. "Review and Conceptual Analysis of the Employee Turnover Process." Psychological Bulletin, 36 (3), 493-521.

Mobley, W., 1986. Pergantian Karyawan : Sebab-Akibat dan Pengendaliannya. 1st ed. Jakarta: Gramedia.

Mueller, J., 2003. Measuring Social Attitude : A Handbook For Research and Practicioners. 2nd ed. New York: Teacher College Press.

Mueller, J., 2005. The Role Of temporal Shiftsin Turnover Processes : It's About Time. Journal Of Applied Psychology, pp. 644-658.

Mueller, J.D.K., Wanberg, C.R., Glomb, T.M \& Ahlburg, D, 2005. The Role of
Temporal Shiftsin Turnover Processes: Its About Time. Journal of Applied Psychology, Volume 4, pp. 644-658.

Peraturan Pemerintah Nomor 37 Tahun 2009 Tentang Guru dan Dosen.

Pinder, C., 2008. Work Motivation in Organizational behavior. New York: Psychology Press.

Price, J.L \& Mueller, C.W, 1981. A Causal Model of Turnover For Nurses. Academy of Management Journal, Volume 24(III), pp. 543-565.

Redmond, B. F., 2009. Lesson 5 : Equity Theory : Is What I Get For My Work Fair Compared To Other. Work Attitude and Motivation. In: Work Attitude and Motivation. The Pennsylvania State University.

Redmond, B. F., 2010. Lesson 5 : Equity Theory : Is What I Get For My Work Fair Compared To Other. Work Attitude and Motivation. In: Work Attitude and Motivation. The Pennsylvania State University: s.n., pp. 20-29.

Robbins, S., 2006. Perilaku Organisasi. Sepuluh ed. Jakarta: PT Indeks Kelompok Gramedia.

Taris, W., Kalimo \& Wilmar, 2002. Inequity at Work : Its Measurment And Asociation With Worker Health. Work \& Stress Journal, Volume 16 , pp. 287-301.

Tyler, T. R, 1989. The psychology of procedural justice: A test of the group-value model. Journal of Personality and Social Psychology, Volume 57, pp. 830838.

Yamin, S., \& Kurniawan, H, 2009. SPSS Complete; Teknik Analisis statistik Terlengkap dengan Sotfware SPSS. 3 ed. Jakarta Selatan: Salemba Infotek. 